\title{
Human effects and degradation processes on the Aegean coastal zone
}

\author{
S. Sütgibi \\ Ege University, Faculty of Education, İmir, Turkey
}

\begin{abstract}
The subject of this study is to explain the human effects and degradation processes on the Aegean coastal zone. The Aegean coastal zone is different from other coastal zones of Turkey because of its geologic structure, geomorphologic evolution and natural environment properties. As a consequence of this, the Aegean Sea and coasts are of great importance to Anatolian civilization history. As is well known, the Aegean coastal zone has been settled since prehistoric ages and is intensively used and settled nowadays. At present, the Aegean coastal zone has also important environmental problems such as salinization of delta soils, pollution of surface and ground water resources and loss of wetlands due to densely agricultural and tourism activities, and heavy urbanization.

Keywords: Aegean coast, human effect, human activities, degradation processes.
\end{abstract}

\section{Introduction}

The Aegean coastal area of Turkey has a coastal strip with $2593 \mathrm{~km}$ of length lying down from Baba foreland in the north to Marmaris bay in the south. The gologic nature, geomorphologic evolution, natural landscape and ecologic characteristics of this coastal zone are different from those of other coasts of Turkey. The mountain ranges lie perpendicular to the sea and flat plains generally extending from east to west take place between them. The long rivers found in these plains have created their large and fertile deltas where they are flowing into the sea by the course of time. These are deltas of Bakırçay, Gediz, Little Meander and Great Meander (Figure 1).

The Aegean sea and its coasts have an important position in Anatolia civilization history due to their geographic environmental characteristics. Adramyttion in Edremit plain, Elaia in Bakırçay delta, Leukai in Gediz delta, 
Smyrna in the east coast of İzmir bay, Clazomenai in Urla peninsula, Teas and Ephesus on the coast of Kuşadası bay, Priene and Miletos in the influx Great Meander, Halicarnassos in Bodrum and Knidos in Datça peninsula are some of the most important examples of coastal cities of ancient times (Figure 1). Convenient climatic conditions and fertile soils in the delta and coastal plains allowing agricultural activities had an important effect on the establishment and development as well as the historical importance of these cities. Furthermore, protected bays and gulfs had an important role in development of sailing and marine commerce, and rich sea products supported economic life [1]. However, although the natural environment in the Aegean zone had a formative effect on social, cultural and economic development previously, this development caused people to force the potential of the natural environment around them by the course of time. For example, agricultural fields became insufficient as the population grew and consequently, agricultural fields were extended toward slopes. Vegetation cover became extinct on these slopes. Forests were cut down and the areas, which were gained, were employed for agricultural purposes (generally olive groves and vineyards). Although marine commerce made sales of the products specific to the Aegean zone such as wine and olive oil increase, more and more trees were used as fuel for pottery intended for transportation and storage. Charcoal and timber export also had significant roles in chopping down trees [2]. Destroying vegetation cover caused the soil-water-plant balance, which is already sensitive, to be violated and soil-erosion accelerated. Deltas growing rapidly in the Aegean coastal areas demonstrate the magnitude of erosion here clearly. Because bays and gulfs were filled due to erosion in Aegean coastal areas, some famous harbour cities such as Ephesus and Miletos had to withdraw. Thus, the human beings, who had affected the environment and violated natural balance, had to re-adapt to the changing environmental characteristics [2].

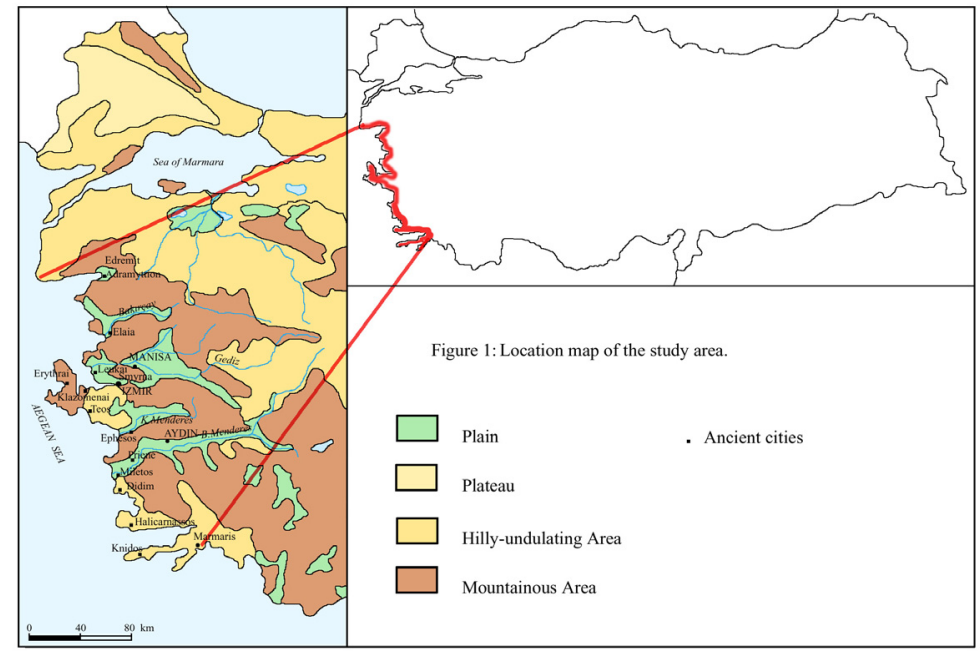

Figure 1: $\quad$ Usage and actual problems of Aegean coastal areas. 
Just like in the past, today, Aegean coastal areas are preferred by people due to its natural environmental characteristics and are also exposed to over-usage. The potential caused by convenient climatic conditions, fertile soils and the activities relating to sea have caused the population to increase rapidly and exploited these resources. Due to over usage, the fertile soils have become salty and pollution has started in rivers and groundwater. Demand for new agricultural fields due to overgrowth population has caused wetlands to dry in these coastal areas just like in other coastal areas in Turkey and consequently, balances of these ecosystems have been violated. In this paper our aim is to emphasize the usage of Aegean coastal areas and explain the problems caused by the human impacts.

\subsection{Population and settlement}

Aegean coastal areas have many settlements from early ages of history. As mentioned before, many ancient cities such as Smyrna, Ephesus, Teos, Miletos, Priene and Clozomenai in the Aegean coast were established and developed depending on convenient geographic environmental conditions offered by the coastal zone. However, anthropogenic effects in Aegean coastal areas have started with settlement from early ages of history.

Although settlement and human activities in Aegean coastal areas have started very early, nowadays they are continuing increasingly. Internal immigration action started in the 1950s especially in Turkey and immigration to the Aegean Region was also very intensive and the population of the region started to grow very rapidly. Naturally, population growth in coastal areas was more intensive compared with that of inland areas. For example, while the population of İzmir, which is the largest settlement in the region and is positioned in the coastal area, was 359372 in 1950, it has reached to 2732669 in 2000. Population growth rate of İzmir, which is $22.3 \%$, is higher than the average rate in Turkey (18.28\%). As far as other settlements in Aegean coastal areas are concerned, their population growth rates are higher than $20 \%$. Population growth rates are much higher especially in the settlements in which tourism is encouraged such as Bodrum, Marmaris, Didim and Kuşadası. Quite high population growth rates were seen like $54.31 \%$ in Bodrum, $63.92 \%$ in Marmaris, $56.58 \%$ in Didim and $41.01 \%$ in Kuşadası in the period between 1990 and 2000 [3]. High growth rates in Aegean coastal areas have caused relevant problems. It has meant that housing demand has increased accordingly and new areas have been made available for housing. This development has become a disadvantageous for fertile agricultural areas in the coastal zones and these areas have been invaded by settlements. Furthermore, some problems such as soil, groundwater and water pollution as well as sea pollution started to emerge because of insufficient substructure as an indicator for overpopulation and unplanned settlement and releasing industrial/domestic wastes to the basins without treatment. In fact, it may be seen that all of the municipalities of the provinces in the region have not had sewage systems and wastewater treatment plants. 
The most serious pollution problem in the Aegean coastal zone has been experienced in İzmir Bay. İzmir Bay was considered to be included in the areas in which pollution started to increase within Mediterranean Basin especially in the 1960s. Naturally, the main reasons of this severe pollution are unplanned urban growth as a result of high population rates and industrialization developing accordingly. On the other hand, İzmir is the largest export harbour in Turkey. Shipment volume is increasing as new buildings and plants are being constructed and opened and also equipped with modern vehicles in the harbour [4]. Pollution loads coming to İzmir Internal Bay were eliminated as a result of completion of the Great Channel project when Güzelbahçe Treatment Plants were taken into operation and recovery processes in the internal bay started. However, beside İzmir city, Gediz, Great Meander and Little Meander rivers also pollute the Aegean Sea. Consequently, the pollution problem in the Aegean Sea cannot be solved completely until the pollution carried by these rivers is prevented. In fact, in a study relating to carbon and combustible matter levels in the sediments of Southern Aegean Sea, it was seen that these values are too high in the coasts where Great Meander and Little Meander rivers are positioned. This result suggests that besides intensive human activities on these coasts, land-originated organic matters carried by Great Meander and Little Meander rivers may cause pollution [5].

High population growth rate and urbanization action in İzmir are not only a problem for the bay but they have also affected Gediz delta in the north of the city. Gediz delta is one of the most important wetlands in Turkey. Overgrowth of İzmir has an important position among many environmental factors affecting the delta. The main city plan of İzmir was prepared to regulate the city in 1973 and the Çiğli-Ulucak-Menemen-Aliağa line was determined as one of the extension directions of the city [6]. Urban growth started especially İzmir Atatürk Organized Industrial Distinct (İAOSB) in the southeast of the delta by executing this plan. Multi-story buildings, malls and road connections, which were constructed by continuing to fill wetlands especially from 1990s, also violate the ecological quality of the area. Stopping hydraulic cycles causes floods and collapses in the area. IAOSB, which has said that the soil collapsed 2-3 m, was affected by floods seriously in the winter months of 2001-2002 [7].

\subsection{Agricultural activities}

The most important human activity, which threatens Aegean coastal areas, is agriculture. Agricultural activities in Aegean coastal areas have always been intensive since early ages. Fertile delta plains, convenient climatic conditions and irrigation potential are very effective on the human activities. Bakırçay, Gediz, Little Meander and Great Meander delta plains take place from north to south. They take place among the most fertile agricultural fields in Turkey and are used intensively. As is well known, the most important effect of intensive agricultural activities in coastal areas are on water systems because groundwater is used excessively for irrigation and therefore, the freshwater-seawater balance, which is already sensitive in coastal areas, is violated. Irrigational agriculture practice is generally applied in the mentioned Aegean coastal plains and cotton, 
corn, rice and vegetables are reproduced. Rivers around and mostly groundwater are used for irrigation. Over-usage of groundwater has violated the fresh waterseawater balance in these areas and caused seawater leak into groundwater. For example, more than 600 water wells exist within the geographic borders of Selçuk County including the Little Meander delta plain and these are used for agricultural irrigation. However, salt was determined in water of the wells in Selçuk plain as a result of measurements performed by DSI İzmir Regional Directorate [8]. Moreover, Somay's study performed in the Selçuk plain supports the mentioned measurements of DSI from the point of view of salt in groundwater [9].

The deltas existing in Aegean coastal areas have important functions beside agricultural activities due to their wetlands. As is well known, wetlands are the ecosystems, which have the highest biologic diversity with the exception of tropical forests. Thus, Aegean coastal areas are one of important coastal ecosystems in Turkey due to their deltas and wetlands. However, wetland drying works, which were started to prevent malaria disease especially in 1930s in these coastal areas just like in other coastal areas in Turkey, have been continued for gaining agricultural areas as a result of overpopulation and accordingly agricultural field demand. For example, many lakes such as Cellat, Akarca and Nohut and swamps in Little Meander delta, Yazır, Karagöl, Afşar, Azap and Karacahayat lakes in Great Meander delta and some of the lagoons existing in the delta were dried during the works intended for preventing Söke plain from overflow. Today, intensive agricultural activities in delta plains including dried areas are continuing. Not only intensive agricultural activities in delta plains but also those continuing along the river basins creating these deltas threaten wetlands because water of these rivers is important for agricultural activities. For example, the first irrigation works in Gediz river basin started in 1940 and then, three dams were constructed on the river and its branches intended for energy generation and irrigation. However, the amount of fresh water reaching the Gediz delta has reduced because of the collected water in the dams and drought in recent years. Therefore, drying endangers large reed areas and swamps existing between the place where the river runs and the fish are trapped. Still, some projects are being executed to prevent this hazardous situation. The problems, which are being experienced in Gediz delta, will be experienced in the future in Little Meander delta also because of four dam projects of DSI on the river and its branches. For example, Beydağ dam, which is one of the most important projects, started to collect water on 9 September 2007.

Another problem caused by agricultural activities is soil and water pollution caused by agricultural inputs (fertilizer and pesticides). For example, the waters of Little Meander and Great Meander fall into the $4^{\text {th }}$ grade water quality because of the nitrogen from nitrite, total phosphorus, lead, cadmium, sulphur; the BOI and $\mathrm{COI}$ values suggest that water pollution is caused by pesticide and fertilizer.

\subsection{Industrial activities}

Aegean coastal areas are among the areas in which intensive industrial activities are performed. Approximately $11 \%$ of Turkish industrial production is made in 
the Aegean region. Oil, food, textile, iron-steel, automotive related industry, electrical equipment, chemistry, tobacco, leather and ceramic main sectors occupy an important position in the region's manufacturing industry. İzmir is the most attractive center for industrial investments. Rich raw material resources, qualified work power and transportation potential caused the development of the industry in İzmir. 55\% of exports by container from Turkey is done via three harbors in İzmir. İzmir performs $8.9 \%$ of Turkish industrial manufacturing, $17.5 \%$ of export and $13 \%$ of import [10].

There are 19 active and planned organized industrial districts in İzmir. Beside these, there are organized industrial districts in other cities of the region such as Aydın, Muğla and Manisa.

Naturally, intensive industrial activities in the Aegean Region have negative effects on coastal areas directly or indirectly because most of the industrial plants take place in important river basins and their wastewater are released to the river without treatment due to insufficient wastewater treatment plants. For example, Manisa with its 12 counties, İzmir with its 4 counties, Kütahya with its 1 county and Uşak city exist in Gediz basin and rapid industrial development has been seen beside high agricultural potential in recent years. Overpopulation and irregular industrialization in the basin cause the loss of agricultural fields and Gediz river is polluted due to discharge of wastewater without treatment. Polluted river water causes a violation of the ecologic balance. Only half of urban wastewater is treated while this rate reduces to $30 \%$ for industrial wastewater in the basin. Approximately 220000 tons/year domestic solid waste and 45000 tons/year industrial solid waste are stored irregularly in the basin [11]. Nif creek from the south also is an important pollution source for Gediz river. Nif creek is quite polluted especially because of intensive and various industrial activities in Kemalpaşa county and domestic wastewater of the county ( $4^{\text {th }}$ Grade) [12].

The delta of Gediz river is the delta in which most serious pollution is experienced in the Aegean coastal areas. 20400 ha of the delta covering an area of 40000 ha in the Aegean coastal areas forms a wetland ecosystem consisting of fresh water and seawater swamps, bays, Salinas and lagoons (Homa, Çilazmak, Kırdeniz). Gediz river delta was included in Ramsar List in 1998 to protect its wetlands. Moreover, a part of 8000 ha was announced as a Wild Life Protection Area by the Forest Ministry in 1982 and it was announced to be a $1^{\text {st }}$ Grade Natural Sit Area completely by the Cultural Ministry in 1999. The delta was announced to be an Archaeological Sit Area and taken under protection due to Leukai ancient city, which exists in the delta and was found in Üçtepeler, which was an island in the Aegean sea. Gediz delta is among the Important Bird Areas (ÖKA) of Turkey due to the birds living in it. More than 200 species of 426 bird species living in Turkey have been observed in the region. Despite more than one protection statues for the delta and its wetland, Atatürk Organized Industrial District consisting of 613 units and İzmir Menemen Leather Free Zone consisting of 189 units exist just east section of the delta. Also, İzmir Wastewater Treatment Plant exists within $1^{\text {st }}$ Grade Natural Sit Area in the southeast section of the delta. The objective of the treatment plant is treatment of wastewater 
before discharging it to İzmir Bay and thus, cleaning the water of the bay. After the plant started to run, odour pollution in the bay started to reduce and its water has been cleaned by the course of time. However, the plant has become a problem for Gediz delta because waste sludge from the treatment process is stored in salt plains of the delta. The plant produces daily 600 tons of nonqualified waste sludge and this sludge is spread over the salt plains illegally in which mud birds reproduce, accommodate and live in winter [6].

Another serious problem in Aegean coastal areas is the third largest Vessel Dismounting Plant in the world and the only one in Turkey at Aliağa existing 50 $\mathrm{km}$ north of İzmir in Aegean coastal areas. In the plant, which is active since 1976, 18 private companies and an official establishment make mostly military vessel dismounting [13]. The most significant environmental effects of vessel dismounting plants existing in some countries such as India, Pakistan, Bangladesh and China are caused by toxic wastes released during vessel dismounting. The main problems around Aliağa are caused by asbestos content of most dismounted vessels, dismounting on the sea rather than docks and oil and lubricator wastes leaking to seawater. Also, because one of the few oil refineries in our country exists in Aliağa, environmental pressures in these coastal areas are increasing day by day.

\subsection{Tourism activities}

The Aegean coastal zone is among the areas in which most intensive tourism activities take place in Turkey because of its natural beauties and cultural values as well as convenient climatic conditions. The benefiting potential from the good climatic conditions increases from Edremit bay coastal areas in the north to the south during the year. For example, if the most suitable seawater temperature is considered to be $22-25^{\circ} \mathrm{C}$ for sea cures, the period lasts averagely for 114 days in Ayvalık, 136 days in İzmir and 131 days in Marmaris. On the other hand, weather temperatures, relative humidity and wind characteristics in the coastal zone offer convenient opportunities for health and sea tourism [14]. In general, it may be said that Aegean coastal areas have a very convenient position with respect to "solar climate" because thermal balance shows positive values during a whole year, sunbathing periods are long and the sunlight reaches to the earth at wide angles. For example, we may see convenient weather temperatures (20-28 ${ }^{\circ} \mathrm{C}$ ) for 125 days in Selçuk, 130 days in Edremit, 134 days in Ayvalık, 132 days in Dikili, 142 dys in İzmir and 125 days in Kuşadası [14]. Convenient relative humidity, precipitation regime and wind conditions during convenient sea bathing temperatures make these areas suitable for every type of recreational and tourism activities in Aegean coastal areas.

Hotel, motel, camping, holiday village and resort house construction have increased depending on tourism especially since the 1960s and 1970s in Aegean coastal areas [1]. Over-usage of the coastal areas has caused many problems. The most important of them is coastal edge line violation. Coastal law forbids construction on the areas close to the sea less than $100 \mathrm{~m}$ [15]. The determination of this strip aims to ensure public access to the coastal areas, open coastal landscape and the prevention of coastal erosion. However, resort houses and 
other tourism facilities were constructed without considering any distance on coastal areas from 1950 s to 1990 s until the coastal law was put into effect. Furthermore, uncontrolled constructions on the coastal areas cause the replacement of the existing natural fields with urban usages and wastewater disposal. Unfortunately, sewage system and treatment plants problems have not been solved completely yet in many settlements. Construction in the coastal zone has been changing the flora and countryside landscape irrevocably. Forests and agricultural fields have been sacrificed to resort house construction. Construction of second houses within the coastal swamps causes a decrease in floor water and consequently, affects agricultural fields behind negatively [16].

The increase in hotel, motel, holiday village and resort construction endangers wetlands and ÖKAs. For example, hotel, motel, holiday village and resort constructions extending from the north and especially from Kuşadas 1 in the south through the Little Meander delta along the coast endanger the delta and especially ÖKAs. Similar problems relating to an increase in second house numbers especially since 1970 s have been experienced in the delta plains of Altınova and Madra creek in the north. As the number of resort houses constructed in a narrow coastal strip previously increased, they started to extend through fertile agricultural fields of the delta plain existing behind the coastal strip and agricultural fields have started to be lost.

Olive production is intensive in the coastal areas between Ayvalık and Edremit bay in the Aegean Region. However, constructions relating to tourism facilities and resort houses endanger olive trees. According to the observations of Edremit Olive Plant Directorate, more than 3 million olive trees were lost between 1990 and 2006 in the coastal areas of Edremit bay. More than 1.5 million of these trees have been sacrificed to second houses and tourism facilities. Approximately 1.5 million of these trees have not been cut but used for decoration. These trees are not useful from the point of view of economy. They dry by the course of time and they are cut by their owners [17].

\section{Other problems}

Aegean coastal areas have been encountering problems caused by fishing and especially fish production along with agricultural, industrial and tourism activities. Aegean coastal areas have an important position in sea product manufacturing of Turkey because of their many fish traps such as Köyceğiz, Güllük, Akköy, Bafa, Karina nad Homa. The share of Aegean coastal areas in this sector, $60 \%$, is the highest in Turkey. There are approximately 350 fish farms in Turkey. 51\% of them exist in Muğla, 30\% of them in İzmir and $6 \%$ of them in Aydın. In total 87\% of them exist in Aegean coastal areas [18]. Although many views, which are inconsistent with each other, exist about environmental effects of fish farms, it is known that especially an increase in farm inputs as a result of increase in the production causes waste loads from the system to increase. Furthermore, they cause negative changes in water column and sediment [19]. 
Another risk for Aegean coastal areas is related to the new constitutional amendment to be put into force by the National Assembly (TBMM). According to the constitution of 1982, the areas which lost forestry quality completely before 31.12 .1981 will be excluded of forestry borders on behalf of the treasury. The new constitutional proposal makes this historical date 23.07.2007. Thus, approximately 3.5 million thousand squire meter of areas which lost forestry quality completely in the recent 26 years will not be considered as forest. Unfortunately, this means that forests are destroyed and their integrity is violated. Approximately $49045 \mathrm{~m}^{2}$ area existing in the Aegean coastal areas may be excluded from forestry fields by the reason that they lost forestry quality completely especially because of forest fires. Then, many bays in the Aegean coastal areas may be opened to construction especially intended for tourism. In fact, forest fires experienced in 2007 in important tourism centres of the Aegean coast such as Bodrum and Çeşme increase these considerations because fires have increased after the legal regulation was heard according to the data provided by the forestry engineers' chamber [20].

\section{Conclusion}

Convenient climatic conditions, cultural and natural attraction, fertile fields and opportunities for benefiting from the sea make the Aegean coastal areas preferable and over-used by people. Coastal cities were established in these coastal areas since early ancient times and environmental assets were exploited. However, rapid growth and over-usage cause erosion and alluvium and consequently, the ancient cities were covered in many places and also they cause harbors to be filled. This means that some environmental changes caused by human usage have been experienced even since early ages of history. Today, usage characteristics, overgrowth population, urbanization and industrialization have caused a very rapid changing process in the Aegean coastal areas. This process harms soils via pollution by wastes and makes them salty. It harms fertile delta plains because agricultural areas have become settlement areas because of unplanned urbanization. Wetlands, which have international importance, are destroyed. It causes many problems such as sea pollution. If this process progresses so rapidly, unfortunately, it will harm ecologic, cultural and landscape values of the Aegean coastal areas.

\section{References}

[1] Koçman A. Ege Bölgesi Kıyı Alanlarının Kaderi ve Geleceği, Türkiye Kıyıları 02 Konferans1 Bildiriler Kitabı, 5-8 Kasım 2002.

[2] [2Kayan İ. Datça Yarımadasında "Eski Knidos" Yerleşmelerini Etkileyen Doğal Çevre Özellikleri, Ankara Üniversitesi Dil ve Tarih-Coğrafya Fakültesi Coğrafya Araştırmaları Dergisi, Sayı 11, 1988.

[3] Turkish Statistical Institute (TURKSTAT)http://www.die.gov.tr/ istatistikler.html (02.10.2007) 
[4] Karadağ A. Kentsel Gelişim Süreci, Çevresel Etkileri ve Sorunları İle İzmir, Titizler Grafik Baskı Hizmetleri, ISBN 975-97139-0-X, 2000.

[5] Aydın A. ve U. Sunlu. Güney Ege Denizi Sedimentlerinde Karbon ve Yanabilen Madde Düzeylerinin Araştırılması, E.Ü. Su Ürünleri Dergisi, Cilt 21, Say1 3-4, 2004.

[6] Uzun A. Gediz Deltasında Yaşanan Koruma Kullanma Çatışması, Üniversite Öğrencileri 2.Çevre Sorunları Kongre Kitabı, 16-17-18 Mayıs 2007.

[7] Onmuş ve diğ. Gediz Deltası'nda Katılımcı Yönetim Planı İçin Öneriler, Türkiye'nin Kıyı ve Deniz Alanları IV. Ulusal Konferansı, Türkiye Kıyıları 02 Konferansı Bildiriler Kitabı, 2002.

[8] Sütgibi S. Delta Ecosystems and Degradational Impacts: Küçük Menderes Delta, International Symposium on Geography-Environment and Culture in the Mediterranean Region,5-8 June 2007, Antalya-Turkey (in pres).

[9] Somay A. M. Hydrogeology of Lower Küçük Menderes River Coastal Wetland, 9 Eylül University Graduate School of Natural and Applied Sciences, 2006.

[10] Ege Bölgesi Sanayi Odası (EBSO), http://www.ebso.org.tr/kurumsal/index. php?sayfa_no $=526(01.10 .2007)$

[11] İzmir Ticaret Odası (IZTO), http://www.izto.org.tr/IZTO/TC/IZTO+Bilgi/ izmir/sorunlar/sorun4.htm (02.10.2007)

[12] Türkiye Çevre Atlası, http://www.cedgm.gov.tr/cevreatlasi.htm (02.10.2007)

[13] Vardar E. Türkiye'de ve Dünyada Gemi Söküm Sanayi ve Çevre, Gemi Mühendisliği ve Sanayimiz Sempozyumu, 24-25 Aralık 2004.

[14] Özgürel M., Koçman A. Sağlık ve Deniz Turizmi Açısından Ege Bölgesi Kıyı Kuşağı İklim Koşullarının İncelenmesi, Coğrafya Araştırmaları, Sayı 4, 1996.

[15] Kıyı Kanunu. T.C. 4.4.1990 Tarihli 3621 Sayılı Kıyı Kanunu, 17.04.199020495 Sayılı Resmi Gazete, 1990.

[16] Kılıçaslan Ç. İkinci Konutların Deniz Kıyılarına Etkisi, Süleyman Demirel Üniversitesi Orman Fakültesi Dergisi, Seri A, Sayı 1, 2006.

[17] İrtem E., Karaman E. Edremit Küçükkuyu arasındaki turizm faaliyetlerinin kıyı alanlarına etkisi ve önerilen yönetim programı, İTÜ Dergisi/d Mühendislik, Cilt 3, Sayı:1, 3-14, 2004.

[18] Turk Aqua Culture, http://www.turkaquaculture.net/ (30.10.2007)

[19] Başaran A.K. ve diğ. Ildır Koyu'nda (İzmir-Ege Denizi) Açık Deniz Ağ Kafeslerde Yapılan Balık Yetiştiriciliğinin Su Kalitesi Üzerine Etkilerinin İzlenmesi, Tarım Bilimleri Dergisi, 13 (1), Ankara Üniversitesi Ziraat Fakültesi, 2006.

[20] Doğan E., Burak S., Akaya A. Türkiye Kıyıları (Kavramsal TanımlamaPlanlama-Kullanım), Beta Basım Yayım Dağıtım A.Ş., 2005. 